\title{
Vetufebrus ovatus n. gen., n. sp. (Haemospororida: Plasmodiidae) vectored by a streblid bat fly (Diptera: Streblidae) in Dominican amber
}

\author{
George $O$ Poinar Jr
}

\begin{abstract}
Background: Both sexes of bat flies in the families Nycteribiidae and Streblidae (Diptera: Hippoboscoidea) reside in the hair or on the wing membranes of bats and feed on blood. Members of the Nycteribiidae transmit bat malaria globally however extant streblids have never been implemented as vectors of bat malaria. The present study shows that during the Tertiary, streblids also were vectors of bat malaria.

Results: A new haemospororidan, Vetufebrus ovatus, n. gen., n. sp., (Haemospororida: Plasmodiidae) is described from two oocysts attached to the midgut wall and sporozoites in salivary glands and ducts of a fossil bat fly (Diptera: Streblidae) in Dominican amber. The new genus is characterized by ovoid oocysts, short, stubby sporozoites with rounded ends and its occurrence in a fossil streblid. This is the first haemosporidian reported from a streblid bat fly and shows that representatives of the Hippoboscoidea were vectoring bat malaria in the New World by the mid-Tertiary.

Conclusions: This report is the first evidence of an extant or extinct streblid bat fly transmitting malaria. Discovering a mid-tertiary malarial parasite in a fossil streblid that closely resembles members of a malarial genus found in nycteribiid bat flies today shows how little we know about the vector associations of streblids. While no malaria parasites have been found in extant streblids, they probably occur and it is possible that streblids were the earliest lineage of flies that transmitted bat malaria to Chiroptera.
\end{abstract}

Keywords: Dominican Republic amber, Fossil bat malaria, Vetufebrus ovatus, n. gen., n. sp

\section{Background}

Amber is known for its ability to preserve vertebrate microbial pathogens. Thus far, there are records of malaria, leishmaniasis and trypanosomiasis associated with insect vectors in amber deposits ranging from 20 to 100 million years of age [1]. Sporogonic stages of the bird malaria, Plasmodium dominicana, occurred in Culex malariager in Dominican amber [2] and developmental stages of Paleohaemoproteus burmacis (Haemospororida: Plasmodiidae) were reported from an Early Cretaceous Burmese amber biting midge (Diptera: Ceratopogonidae) [3]. The present study describes the sporogonic stages of a new genus of bat malaria in a Dominican amber fossil streblid [4]. Extant streblids have never been implicated as vectors of bat malaria,

Correspondence: poinarg@science.oregonstate.edu

Department of Zoology, Oregon State University, Corvallis, OR 97331, USA however members of the closely related family Nycteribiidae transmit bat malaria globally [5,6] (Table 1). Since both sexes of streblid bat flies (Diptera: Hippoboscoidea: Streblidae) feed on the blood of bats and reside in the hair or on the wing membranes [7-9], they would be excellent vectors of bat malaria.

\section{Methods}

\section{Specimen}

The fossil streblid is in a piece of amber $5 \mathrm{~mm}$ long by $4 \mathrm{~mm}$ wide by $4 \mathrm{~mm}$ deep (Figure 1). Observations, drawings, and photographs were made with a Nikon SMZ-10 R stereoscopic microscope and Nikon Optiphot compound microscope with magnifications up to $600 \times$.

Since it was not possible to photograph the malarial organisms without polishing away portions of the fly,
C Biomed Central

(c) 2011 Poinar; licensee BioMed Central Ltd. This is an Open Access article distributed under the terms of the Creative Commons Attribution License (http://creativecommons.org/licenses/by/2.0), which permits unrestricted use, distribution, and reproduction in any medium, provided the original work is properly cited. 
Table 1 Hippoboscoidea vectors of malaria

\begin{tabular}{|c|c|c|c|}
\hline Vector & Malaria type & Vertebrate & Reference \\
\hline \multicolumn{4}{|l|}{ Hippoboscidae } \\
\hline Icosta hirsuta & $\begin{array}{l}\text { Haemoproteus } \\
\text { lophortyx }\end{array}$ & birds & {$[8]$} \\
\hline I. rufiventris & H. lophortyx & birds & {$[8]$} \\
\hline Lynchia hirsuta & H. lophortyx & birds & [20] \\
\hline Microlynchia pusilla & H. columbae & birds & [21] \\
\hline M. pusulla & H. maccallumi & birds & [22] \\
\hline M. pusilla & H. sacherovi & birds & [22] \\
\hline $\begin{array}{l}\text { Ornithomyia } \\
\text { avicularia }\end{array}$ & H. mansoni & birds & [23] \\
\hline $\begin{array}{l}\text { Ornithomyia } \\
\text { lagopodia }\end{array}$ & H. mansoni & birds & [24] \\
\hline $\begin{array}{l}\text { Pseudolynchia } \\
\text { brunnea }\end{array}$ & H. columbae & birds & [21] \\
\hline P. canariensis & H. columbae & birds & {$[25]$} \\
\hline P. canariensis & H. maccallumi & birds & {$[22]$} \\
\hline P. capensis & H. columbae & birds & {$[21]$} \\
\hline P. maura & H. columbae & birds & {$[21]$} \\
\hline $\begin{array}{l}\text { Stilbometopa } \\
\text { impressa }\end{array}$ & H. lophortyx & birds & {$[26]$} \\
\hline \multicolumn{4}{|l|}{ Nycteribiidae } \\
\hline Basilia sp. & $\begin{array}{l}\text { Polychromophilus } \\
\text { deanei }\end{array}$ & bats & {$[12]$} \\
\hline Listropoda sp. & $?$ & bats & [27] \\
\hline Nycteribia dentata & Polychromophilus sp. & bats & [28] \\
\hline N. kolenatii & P. murinus & bats & [10] \\
\hline N. parvula & P. melanipherus & bats & [29] \\
\hline Penicillidia fulvida & Polychromophilus sp. & bats & [11] \\
\hline Penicillidia spp. & Polychromophilus sp. & bats & [13] \\
\hline
\end{tabular}

photographs had to be taken through the thickness of the amber matrix as well as the width of the body wall of the vector. Adobe Photoshop was used to enlarge the photos and obtain the clearest images.

\section{Locality}

The amber with the bat fly came from La Búcara mine in the Cordillera Septentrional of the Dominican Republic. Dating of Dominican amber is still controversial with the latest purposed age of 20-15 mya based on foraminifera [10] and the earliest as 45-30 mya based on coccoliths [11]. In addition, Dominican amber is secondarily deposited in sedimentary rocks, which makes a definite age determination difficult [12]. A range of ages for Dominican amber is possible since the amber is associated with turbiditic sandstones of the Upper Eocene to Lower Miocene Mamey Group [13]. Dominican amber was produced by the leguminous tree, Hymenaea protera Poinar [14] and a re-construction of the Dominican amber forest based on amber fossils indicated that the environment was similar to that of a present day tropical moist forest [15].

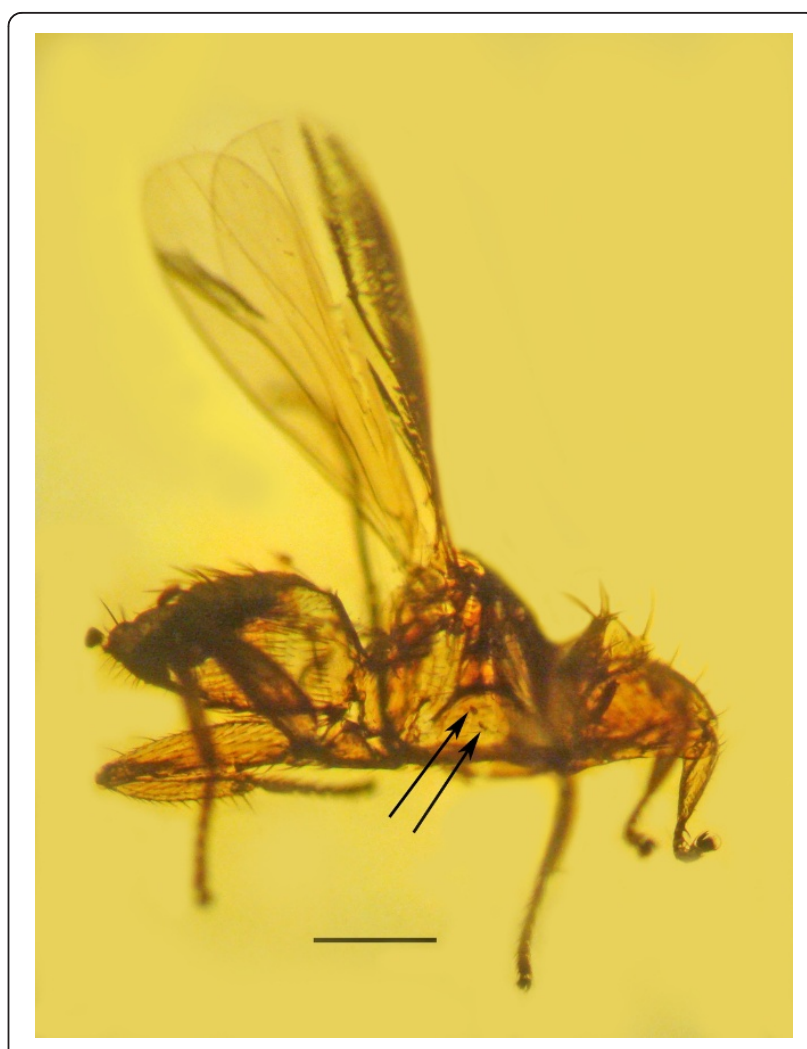

Figure 1 Two oocysts. Two oocysts (arrows) of Vetufebrus ovatus n. gen., n. sp. on the gut wall of a Dominican amber streblid bat fly. $\operatorname{Bar}=272 \mu \mathrm{m}$.

\section{Results and Discussion}

Description of malarial pathogen

Phylum Apicomplexa Levine, 1970

Class Aconoidasida Mehlhorn, Peters \& Haberkorn, 1980

Order Haemospororida Danilewsky, 1885

The description is based on two oocysts and sporozoites in the oocysts and salivary glands/secretions of a fossil streblid bat fly [4].

Vetufebrus Poinar n. gen. (Figures 1, 2, 3 and 4)

Description. Oocysts small, oval, with nucleated cells 3-5 $\mu \mathrm{m}$ in diameter and developing sporozoites 7-10 $\mu \mathrm{m}$ in length; sporozoites in salivary glands and ducts stubby, with rounded ends, $8-10 \mu \mathrm{m}$ in length; occurs in a Dominican amber streblid bat fly [4].

Type species: Vetufebrus ovatus Poinar

Vetufebrus ovatus Poinar, n. sp.

Description: Oocysts brown; oocyst A, $32 \mu \mathrm{m} \times 15$ $\mu \mathrm{m}$; surrounding membrane $1.2-1.4 \mu \mathrm{m}$ wide, containing dark nucleated cells 3-5 $\mu \mathrm{m}$ in diameter and developing sporozoites 7-10 $\mu \mathrm{m}$ in length; oocyst B, $29 \mu \mathrm{m} \times$ $17 \mu \mathrm{m}$, containing dark nucleated cells $3-5 \mu \mathrm{m}$ in diameter and developing sporozoites 7-10 $\mu \mathrm{m}$ in length; surrounding membrane 1.2-1.4 $\mu \mathrm{m}$ wide; sporozoites in 


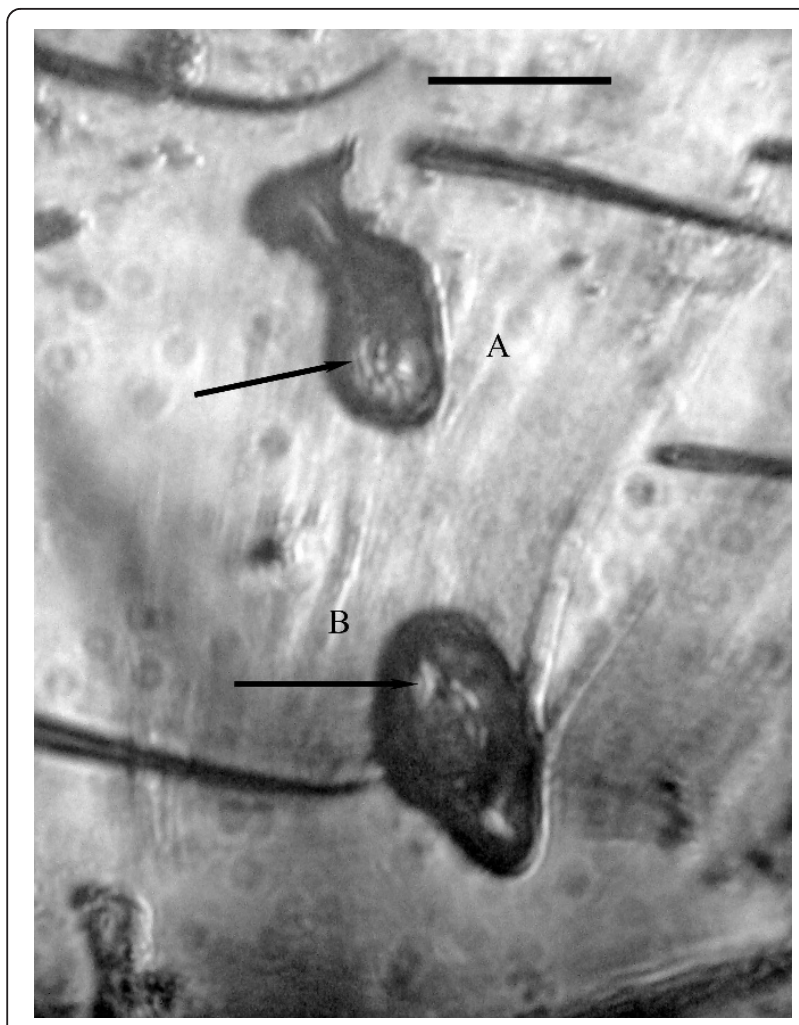

Figure 2 Oocysts A and B of Vetufebrus ovatus. Oocysts A and B of Vetufebrus ovatus n. gen., n. sp. attached to the gut wall of a Dominican amber streblid bat fly. Arrows show developing sporozoites inside oocysts. Bar $=33 \mu \mathrm{m}$.

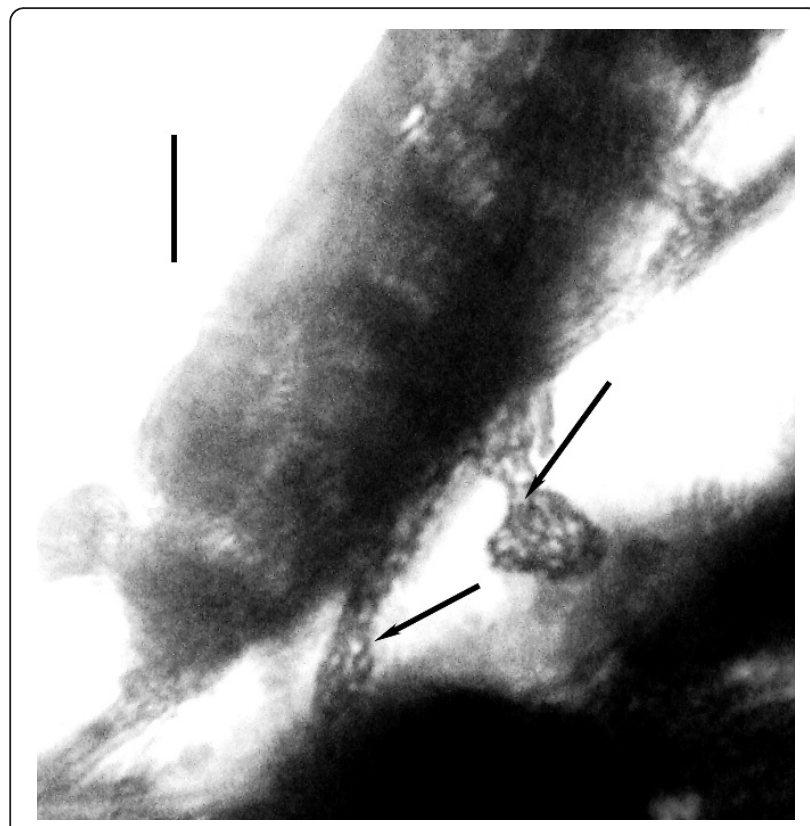

Figure 3 Sporozoites (arrows) of Vetufebrus ovatus. Sporozoites (arrows) of Vetufebrus ovatus n. gen., n. sp. in salivary glands and ducts of a Dominican amber streblid bat fly. Bar $=20 \mu \mathrm{m}$.

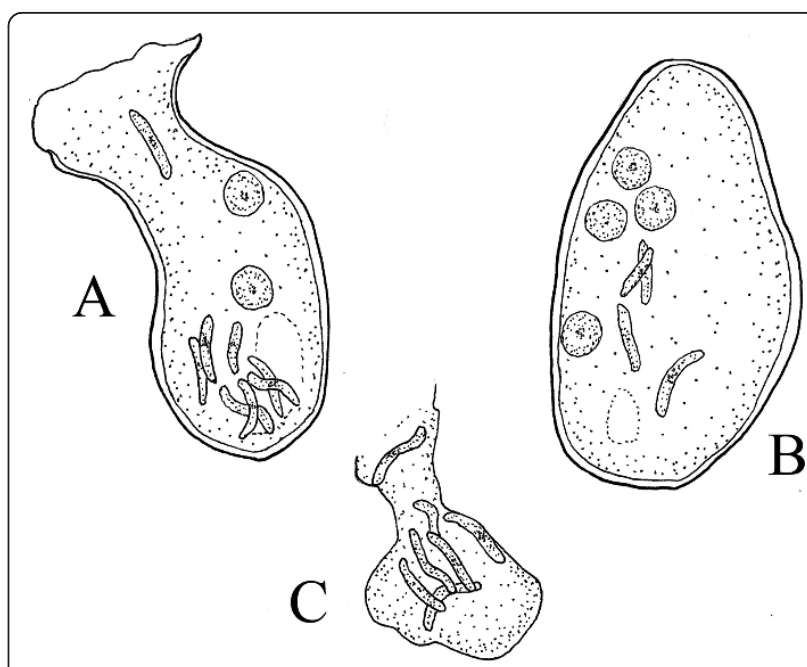

Figure 4 Oocysts of Vetufebrus ovatus. A and B. Oocysts of Vetufebrus ovatus n. gen., n. sp. containing nucleated cells and developing sporozoites in a Dominican amber streblid bat fly. C. Sporozoites of Vetufebrus ovatus n. gen., n. sp. in a salivary gland secretion of a Dominican amber streblid bat fly. Bar $=27 \mu \mathrm{m}$.

salivary glands/secretions short, stubby, with rounded ends, $8-10 \mu \mathrm{m}$ in length.

Etymology: The generic name is from the Latin "vetus" for old and the Latin "febris" for fever. The specific epithet is from the Latin "ovatus" for ovate, referring to the shape of the oocysts.

Holotype. Specimen (accession \# D-7-239) deposited in the Poinar amber collection maintained at Oregon State University, Corvallis, Oregon.

Locality: La Búcara amber mine $\left(19^{\circ} 13^{\prime} \times 70^{\circ} 40^{\prime}\right)$ in the northern portion of the Dominican Republic.

\section{Conclusions}

The present study represents the first description of a haemosporidian reported from a streblid bat fly and shows that representatives of the Hippoboscoidea were vectoring bat malaria in the mid-Tertiary. The presence of sporozoites in salivary glands and ducts indicates that the streblid was a successful vector of Vetufebrus.

Bats are infected with four genera of malaria: Plasmodium, Hepatocystis, Nycteria and Polychromophilus [5,6]. Species of the former three genera infect Old World bats while Polychromophilus occurs globally and is the only bat malaria reported from the New World [16]. All known strains of Polychromophilus are vectored by nycteriibid flies of the genera Nycteribia, Penicillidia and Basilia (Table 2).

The sporogonic stages of Polychromophilus are characterized by round, slow growing oocysts attached to 
Table 2 Sporogonic stages of bat malaria in Hippoboscoidea (all Nycteriibidae except for Vetufebrus in a fossil streblid).

\begin{tabular}{|c|c|c|c|c|}
\hline Malaria & Vector & Oocyst & Sporozoite & Reference \\
\hline Vetufebrus ovatus & Fossil streblid & $\begin{array}{l}35 \times 15,29 \times 17 \\
\text { oval }\end{array}$ & $\begin{array}{l}\text { 7-10, stubby } \\
\text { ends rounded }\end{array}$ & Present study \\
\hline P. deanei & Basilia sp. & 60 , round & 8, thick & {$[12]$} \\
\hline P. melanipherus & Nycteribia parvula & $?$ & $?$ & [29] \\
\hline P. murinus & Nycteribia kolenatii & 57-71, round & 7.4 & [10] \\
\hline Polychromophilus sp. & Nycteribia dentata & $?$ & $\begin{array}{l}\text { 7, stubby } \\
\text { ends rounded }\end{array}$ & [28] \\
\hline Polychromophilus sp. & Penicillidia fulvida & $\begin{array}{l}\text { oval, } 31 \times 10 \\
57 \times 47\end{array}$ & $\begin{array}{l}13, \text { thick, } \\
\text { blunt ends }\end{array}$ & [11] \\
\hline Polychromophilus sp. & $\begin{array}{l}\text { P. dufouri } \\
\text { P. conspicua }\end{array}$ & $?$ & $\begin{array}{l}\text { stubby, } \\
\text { blunt ends }\end{array}$ & {$[5,13]$} \\
\hline Polychromophilus? & Listropoda sp. & $?$ & $\begin{array}{l}6.3 \text {, stubby, } \\
\text { blunt ends }\end{array}$ & {$[5,27]$} \\
\hline
\end{tabular}

All measurements in microns.

the midgut of the vector and short, stubby sporozoites with rounded ends [5]. The mature round oocysts of Polychromophilus spp. contrast with the small oval oocysts of Vetufebrus (Table 2)(Figures 2, 4A, B). However, Adam and Landau [17] noted a small $(31 \times 10$ $\mu \mathrm{m})$, oval Polychromophilus oocyst in the nycteribiid fly, Penicillidia fulvida Bigot, 1889. It is likely that this oval oocyst in the nycteribiid was still developing, which could be the case with the two oocysts of Vetufebrus. While the sporozoites noted in the two oocysts of Vetufebrus are similar in size and shape to those in the salivary glands, it is possible that some of the salivary gland sporozoites originated from an earlier infection.

Short and stubby sporozoites with rounded ends as reported here for Vetufebrus (Figures 3, 4C) are characteristic of Polychromophilus infections [17-19](Table 2) and the dimensions of Vetufebrus sporozoites fall within the range of some Polychromophilus spp. (Table 2). While Vetufebrus could represent an early lineage of Polychromophilus, this is unclear due to the small size of the oocysts. Also bat malaria has not been found in extant streblids even though species of the closely related Nycteribiidae carry bat malaria (Table 1). Adam \& Landau [17] found no malarial stages in the streblids, Raymondia simplex Jobling 1954, R. seminuda Jobling, 1954 and $R$. leleupi Jobling 1954 while searching for vectors of Polychromophilus in the Congo Republic. Also, Garnham [5] found no sporogonic stages of malaria in African streblids.

In accordance with section 8.6 of the ICZN's International Code of Zoological

Nomenclature, copies of this article are deposited at the following five publicly accessible libraries: Natural History Museum, London, UK; American Museum of Natural History, New York, USA; Museum National d'Histoire Naturelle, Paris, France; Russian Academy of
Sciences, Moscow, Russia; Academia Sinica, Taipei, Taiwan.

\section{Acknowledgements}

I thank Alex Brown for supplying the specimen and Jake Jacobson and Roberta Poinar for commenting on earlier drafts of the manuscript.

Authors' contributions

GP discovered the haemosporidian, designed and wrote the paper and supplied the figures.

\section{Competing interests}

The author declares that they have no competing interests.

Received: 31 October 2011 Accepted: 7 December 2011 Published: 7 December 2011

\section{References}

1. Poinar $G \mathrm{Jr}$ : The Origin of insect-borne human diseases as revealed in amber. Amer Entomologist 2011, 57:170-178.

2. Poinar GO Jr: Plasmodium dominicana n. sp. (Plasmodiidae: Haemospororida) from Tertiary Dominican amber. Syst Parasitology 2005, 61:47-52.

3. Poinar G Jr, Telford SR: Paleohaemoproteus burmacis gen. n., sp. n. (Haemospororida: Plasmodiidae) from an Early Cretaceous biting midge (Diptera: Ceratopogonidae). Parasitology 2005, 131:79-84.

4. Poinar GO Jr, Brown AE: The first fossil streblid bat fly, (Diptera: Hippoboscoidea; Streblidae). Syst Parasitology 2012.

5. Garnham PCC: Malaria parasites and other Haemosporida. Oxford: Blackwell Scientific Publications; 1966.

6. Rosin G, Landau I, Hugot J-P: Considérations sur le genre Nycteria (Haemoproteidae) parasite de Microchiroptères africans avec description de quatre espèces nouvelles. Ann Parastiologie (Paris) 1978, 53:447-459.

7. Wenzel RL, Peterson BV: Streblidae. In Manual of Nearctic Diptera. Volume 1. Edited by: McAlpine, JF. Monograph 27. Ottawa: Agriculture Canada Research Branch; 1981:1293-1301.

8. Lloyd JE: Louse flies, keds, and related flies (Hippoboscoidea). In Medical and Veterinary Entomology. Edited by: Mullen G, Durden L. New York: Academic Press; 2002:349-362.

9. Dick CW, Patterson BD: Bat flies: Obligate ectoparasites of bats. In Micromammals and Macroparasites: From Evolutionary Ecology to Management. Edited by: Morand S, Krasnov BR, Poulin R. Toky: SpringerVerlag; 2006:179-194.

10. Iturralde-Vinent MA, MacPhee RDE: Age and Paleogeographic origin of Dominican amber. Science 1996, 273:1850-1852. 
11. Schlee D: Das Bernstein-Kabinett. Stuttg Beitr Naturkunde (C) 1990, 28:1-100.

12. Poinar GO Jr, Mastalerz M: Taphonomy of fossilized resins: determining the biostratinomy of amber. Acta Geol Hisp 2000, 35:171-182.

13. Draper G, Mann P, Lewis JF: Hispaniola. In Caribbean geology: an introduction. Edited by: Donovan S, Jackson TA. Kingston, Jamaica: The University of the West Indies Publishers' Association; 1994:129-150.

14. Poinar GO Jr: Hymenaea protera sp.n. (Leguminosae: Caesalpinoideae) from Dominican amber has African affinities. Experientia 1991, 47:1075-108210.

15. Poinar GO Jr, Poinar R: The Amber Forest Princeton, NJ: Princeton Univ. Press; 1999.

16. Gardner RA, Molyneux DH: Polychromophilus murinus: a malarial parasite of bats: life- history and ultrastructural studies. Parasitology 1988, 96:591-605.

17. Adam JP, Landau I: Developmental stages of Polychromophilus sp., a parasite of insectivorous bats from the Congo-Brazzaville, in the nycteribiid fly Penicillidia fulvida Bigot 1889. Trans Royal Soc Trop Med Hyg 1973, 67:5-6

18. Garnham PCC, Lainson R, Shaw JJ: A contribution to the study of the haematozoon parasites of bats. A new mammalian haemoproteid, Polychromophilus deanei n. sp. Mem Inst Oswaldo Cruz 1971, 69:119-125.

19. Mer GG, Goldblum N: A haemosporidian of bats. Nature 1947, 159:444.

20. O'Roke EC: The morphology, transmission, and life-history of Haemoproteus lophortyx O'Roke, a blood parasite of the California Valley Quail. Univ California Publ Zool 1930, 36:1-51.

21. Huff CG: Studies on Haemoproteus of mourning doves. Amer J Hyg 1932. 16:618-623.

22. Bequaert JC: The Hipppoboscidae or louse-flies (Diptera) of mammals and birds. Part 1. Structure, physiology and natural history. Entomologica Americana 1953, 32:1-209.

23. Baker JR: The transmission of Haemoproteus sp. of English wood-pigeons by Ornithomyia avicularia. J Protozology 1963, 13:406-408.

24. Sanbon LW: Remarks on the avian haemoprotozoa of the genus Leucocytozoon Danilewsky. J Trop Med Hyg 1909, 12:37-38.

25. Adie H: The sporogony of Haemoproteus columbae. Indian J Med Res 1915, 2:671-680

26. Tarshis IB: Transmission of Haemoproteus lophortyx O'Roke of the California quail by hippoboscid flies of the species Stilobometopa impressa (Bigot) and Lynchia hirsuta Ferris. Exp Parasitol 1955, 4:464-492.

27. Corradetti A: Alcuni protozoi parassiti di Nycteribiidae del genere Listopoda. Ann di Igiene 1936, 46:444-448.

28. Garnham PCC: The zoogeography of Polychromophilus and description of a new species of a gregarine (Lankestria galliardi). Ann Parasitol Hum Comp 1973, 48:231-242.

29. Garnham PCC: Polychromophilus species in insectivorous bats. Trans Royal Soc Trop Med Hyg 1973, 67:2-3.

doi:10.1186/1756-3305-4-229

Cite this article as: Poinar: Vetufebrus ovatus n. gen., n. sp.

(Haemospororida: Plasmodiidae) vectored by a streblid bat fly (Diptera:

Streblidae) in Dominican amber. Parasites \& Vectors 2011 4:229.

\section{Submit your next manuscript to BioMed Central and take full advantage of:}

- Convenient online submission

- Thorough peer review

- No space constraints or color figure charges

- Immediate publication on acceptance

- Inclusion in PubMed, CAS, Scopus and Google Scholar

- Research which is freely available for redistribution 